\title{
PENCEGAHAN DAN PENATALAKSANAAN INFEKSI HIVIAIDS PADA KEHAMILAN
}

\author{
Donel Suhaimi, ${ }^{1}$ Maya Savira, ${ }^{2}$ Sofie R. Krisnadi ${ }^{3}$ \\ ${ }^{1}$ Bagian Obstetri dan Ginekologi Fakultas Kedokteran Riau/Rumah Sakit Arifin Ahmad Pekanbaru \\ ${ }^{2}$ Bagian Mikrobiologi Fakultas Kedokteran Universitas Riau Pekanbaru \\ ${ }^{3}$ Bagian Obstetri dan Ginekologi Fakultas Kedokteran Universitas Padjadjaran/Rumah Sakit Hasan \\ Sadikin, Bandung
}

\begin{abstract}
ABSTRAK
Acquired immunodeficiency syndrome (AIDS) adalah penyakit yang disebabkan oleh infeksi virus human immunodeficiency virus (HIV). AIDS dikarakteristikkan sebagai penyakit imunosupresif berat yang sering dikaitkan dengan infeksi oportunistik dan tumor ganas serta degenerasi susunan saraf pusat. Penyebaran HIV ini berkembang dengan cepat dan mengenai wanita dan anak-anak. AIDS menyebabkan kematian lebih dari 20 juta orang setahun. Tahun 2003 diperkirakan 700.000 bayi baru lahir terinfeksi HIV di seluruh dunia. Angka morbiditas dan mortalitas yang disebabkan oleh HIV semakin meningkat dan merupakan masalah kesehatan masyarakat yang paling penting di semua negara. Penggunaan obat antivirus seperti highly active antiretroviral therapy (HAART) dan persalinan berencana dengan seksio sesaria telah menurunkan angka transmisi perinatal mother to child trasmission (MTCT) penyakit ini dari 30\% menjadi 20\%. Manejemen antenatal, persalinan, dan perawatan pascasalin yang terkontrol dengan baik pada ibu hamil dengan HIV dapat mencegah transmisi perinatal.
\end{abstract}

Kata kunci : AIDS, HAART, MTCT

\section{PREVENTION AND MANAGEMENT OF HIV INFECTION (AIDS) IN PREGNANCY}

\begin{abstract}
Acquired immunodeficiency syndrome (AIDS) is a disease which caused by human immunodeficiency virus (HIV). Characteristic of AIDS is due to severe immunosupresive disease which related to opportunistic infection, malignant tumour and central nervous system degeneration. HIV spread widely and mostly infect women and children. Mortality rate of AIDS are more than 20 million people per year. In 2003, 700,000 newborn were infected by HIV in the world. Morbidity and mortality rate of HIV are highly increase dan become an important public health problem in all around the world. Using of antiviral drugs like highly active antiretroviral therapy (HAART) and ceasarean labor has decreased the perinatal transmission (mother-to-child trasmission=MTCT) rate of this disease from $30 \%$ to $20 \%$. The intensive control in management of antenatal care, labor and delivery for the pregnant women with HIV can prevent the perinatal transmission.
\end{abstract}

Key words: AIDS, HAART, MTCT

\footnotetext{
Alamat Korespondensi:

dr. Donel Suhaimi, SpOG

Bagian Obstetri dan Ginekologi Fakultas Kedokteran Riau/Rumah Sakit Arifin Ahmad Pekanbaru

Jl. Diponegoro 2 Pekan Baru. Email: donelmy@yahoo.com.
} 


\section{PENDAHULUAN}

Acquired immunodeficiency syndrome (AIDS) adalah penyakit yang disebabkan oleh infeksi human immunodeficiency virus (HIV). ${ }^{1,2}$ Penyebaran HIV ini berkembang dengan cepat dan mengenai wanita dan anak-anak. Acquired immunodeficiency syndrome menyebabkan kematian lebih dari 20 juta orang setahun. ${ }^{3}$ Saat ini di seluruh dunia kira-kira 40 juta orang dewasa berusia 15-45 tahun yang hidup dengan infeksi HIV. Tahun 2003 diperkirakan 700.000 bayi baru lahir terinfeksi HIV. ${ }^{4,5}$

Angka morbiditas dan mortalitas yang disebabkan oleh HIV semakin meningkat dan merupakan masalah kesehatan masyarakat yang paling penting di seluruh dunia. Hingga saat ini belum ditemukan imunisasi profilaksis atau pengobatan AIDS, meskipun demikian terapi antiretrovirus seperti highly active antiretroviral therapy (HAART) tetap dikembangkan. Penggunaan obat antivirus dan persalinan berencana dengan seksio sesaria telah menurunkan angka transmisi perinatal penyakit ini dari $30 \%$ menjadi $20 \%$. AIDS dikarakteristikkan sebagai penyakit imunosupresif berat yang sering dikaitkan dengan infeksi oportunistik dan tumor ganas serta degenerasi susunan saraf pusat. HIV menimbulkan infeksi berbagai macam sistem sel imun, termasuk $\mathrm{CD} 4^{+}$, makrofag, dan sel dendrit. ${ }^{5,6}$

\section{STRUKTUR HIV}

Partikel HIV adalah virus RNA yang ber-envelop, berbentuk bulat sferis dengan diameter 80-120 $\mathrm{nm}$. Partikel yang infeksius terdiri dari dua untai single stranded RNA positif yang berada di dalam inti protein virus (ribonukleoprotein) dan dikelilingi oleh lapisan envelope fosfolipid yang ditancapi oleh 72 buah tonjolan (spikes) glikoprotein (Gambar 1). Envelope polipeptida terdiri dari dua subunit yaitu glikoprotein luar (gp120) yang merupakan tempat ikatan reseptor

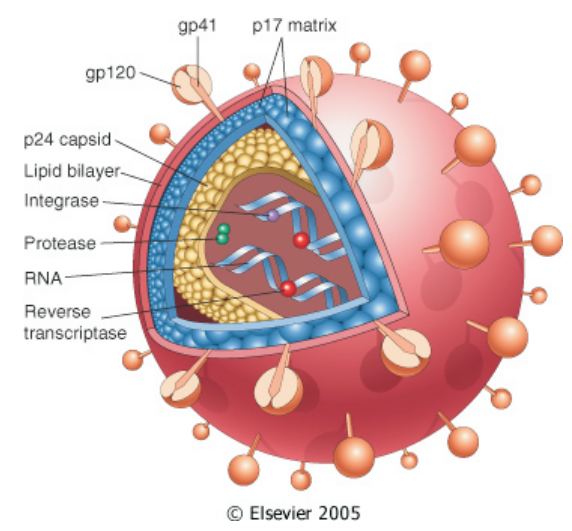

Gambar 1 Struktur HIV

Sumber: Abbas dan Lichtman ${ }^{8}$ (receptor binding) $\mathrm{CD}^{+}$dan glikoprotein transmembran (gp41) yang akan bergabung dengan envelope lipid virus. Protein-protein pada membran luar ini terutama berfungsi untuk mediasi terjadinya ikatan dengan sel $\mathrm{CD} 4^{+}$dan reseptor kemokin. ${ }^{7.8}$

Pada permukaan dalam envelope lipid virus dilapisi oleh protein matriks ( $p 17)$, yang kemungkinan berperan penting dalam menjaga integritas struktural virion. Envelope lipid terbungkus dalam protein kapsid yang berbentuk ikosahedral (p24) dan matriks p17. Protein kapsid mengelilingi inti dalam virion sehingga membentuk 'cangkang' di sekeliling material genetik. Protein nukleokapsid terdapat dalam 'cangkang' tersebut dan berikatan langsung dengan molekul-molekul RNA. ${ }^{8}$

\section{PATOGENESIS}

Partikel-partikel virus HIV yang akan memulai proses infeksi biasanya terdapat di dalam darah, sperma atau cairan tubuh lainnya dan dapat menyebar melalui sejumlah cara. Cara yang paling umum adalah transmisi seksual melalui mukosa genital. Keberhasilan transmisi virus itu sendiri sangat bergantung pada viral load individu yang terinfeksi. Viral load ialah perkiraan jumlah copy RNA per mililiter serum atau plasma penderita. Apabila virus ditularkan pada inang yang belum terinfeksi, maka akan terjadi viremia transien dengan kadar yang tinggi, virus menyebar luas dalam tubuh inang. Sementara sel yang akan terinfeksi untuk pertama kalinya tergantung pada bagian mana yang terlebih dahulu dikenai oleh virus, bisa $\mathrm{CD} 4^{+}$sel $\mathrm{T}$ dan manosit di dalam darah atau $\mathrm{CD}^{+}$sel $\mathrm{T}$ dan makrofag pada jaringan mukosa. ${ }^{7,9,10}$

Ketika HIV mencapai permukaan mukosa, maka ia akan menempel pada limfosit-T $\mathrm{CD}^{+}$atau makrofag (atau sel dendrit pada kulit). Setelah virus ditransmisikan secara seksual melewati mukosa genital, ditemukan bahwa target selular pertama virus adalah sel dendrit jaringan (dikenal juga sebagai sel Langerhans) yang terdapat pada epitel servikovaginal, dan selanjutnya akan bergerak dan bereplikasi di kelenjar getah bening setempat. Sel dendritik ini kemudian berfusi dengan limfosit $\mathrm{CD} 4^{+}$yang akan bermigrasi kedalam nodus limfatikus melalui jaringan limfatik sekitarnya. Dalam jangka waktu beberapa hari sejak virus ini mencapai nodus limfatikus regional, maka virus akan menyebar secara hematogen dan tinggal pada berbagai kompartemen jaringan. Nodulus limfatikus maupun ekuivalennya (seperti plak Peyeri pada usus) pada akhirnya akan mengandung virus. Selain itu, HIV dapat langsung mencapai aliran darah dan tersaring melalui nodulus limfatikus regional. Virus ini bereproduksi dalam nodus limfatikus dan 
kemudian virus baru akan dilepaskan. Sebagian virus baru ini dapat berikatan dengan limfosit $\mathrm{CD}^{+}$yang berdekatan dan menginfeksinya, sedangkan sebagian lainnya dapat berikatan dengan sel dendrit folikuler dalam nodus limfatikus. ${ }^{7,9,10}$

Fase penyakit HIV berhubungan dengan penyebaran virus dari tempat awal infeksi ke jaringan limfoid di seluruh tubuh. Dalam jangka waktu satu minggu hingga tiga bulan setelah infeksi, terjadi respons imun selular spesifik HIV. Respons ini dihubungkan dengan penurunan kadar viremia plasma yang signifikan dan juga berkaitan dengan awitan gejala infeksi HIV akut. Selama tahap awal, replikasi virus sebagian dihambat oleh respons imun spesifik HIV ini, namun tidak pernah terhenti sepenuhnya dan tetap terdeteksi dalam berbagai kompartemen jaringan, terutama jaringan limfoid. Sitokin yang diproduksi sebagai respons terhadap HIV dan mikroba lain dapat meningkatkan produksi HIV dan berkembang menjadi AIDS. ${ }^{7,9,10}$

Sementara itu sel dendrit juga melepaskan suatu protein manosa yang berikatan dengan lektin yang sangat penting dalam pengikatan envelope HIV. Sel dendrit juga berperan dalam penyebaran HIV ke jaringan limfoid. Pada jaringan limfoid sel dendrit akan melepaskan HIV ke CD4 ${ }^{+}$sel T melalui kontak langsung sel ke sel. Dalam beberapa hari setelah terinfeksi HIV, virus melakukan banyak sekali replikasi sehingga dapat dideteksi pada nodul limfatik. Replikasi tersebut akan mengakibatkan viremia sehingga dapat ditemui sejumlah besar partikel virus HIV dalam darah penderita. Keadaan ini dapat disertai dengan sindrom HIV akut dengan berbagai macam gejala klinis baik asimtomatis maupun simtomatis. Viremia akan menyebabkan penyebaran virus ke seluruh tubuh dan menyebabkan infeksi sel T helper, makrofag, dan sel dendrit di jaringan limfoid perifer. ${ }^{9}$

Infeksi ini akan menyebabkan penurunan jumlah sel $\mathrm{CD}^{+}$yang disebabkan oleh efek sitopatik virus dan kematian sel. Jumlah sel $\mathrm{T}$ yang hilang selama perjalanan dari mulai infeksi hingga AIDS jauh lebih besar dibanding jumlah sel yang terinfeksi, hal ini diduga akibat sel $T$ yang diinfeksi kronik diaktifkan dan rangsang kronik menimbulkan apoptosis. Sel dendritik yang terinfeksi juga akan mati. ${ }^{7}$

Penderita yang telah terinfeksi virus HIV memiliki suatu periode asimtomatik yang dikenal sebagai periode laten. Selama periode laten tersebut virus yang dihasilkan sedikit dan umumnya sel $T$ darah perifer tidak mengandung virus, tetapi kerusakan $\mathrm{CD}^{+}$sel $\mathrm{T}$ di dalam jaringan limfoid terus berlangsung selama periode laten dan jumlah $\mathrm{CD}^{+}$sel $\mathrm{T}$ tersebut terus menurun di dalam sirkulasi darah. Pada awal perjalanan penyakit, tubuh dapat cepat menghasilkan $\mathrm{CD}^{+}$sel $\mathrm{T}$ baru untuk menggantikan $\mathrm{CD}^{+}$sel $\mathrm{T}$ yang rusak. Tetapi pada tahap ini, lebih dari $10 \% \mathrm{CD}^{+}$sel T di organ limfoid telah terinfeksi. Seiring dengan lamanya perjalanan penyakit, siklus infeksi virus terus berlanjut yang menyebabkan kematian sel $\mathrm{T}$ dan penurunan jumlah $\mathrm{CD} 4^{+}$sel $\mathrm{T}$ di jaringan limfoid dan sirkulasi. ${ }^{9,11}$

Selama fase lanjutan (kronik) infeksi HIV ini penderita akan rentan terhadap infeksi lain dan respons imun terhadap infeksi ini akan merangsang produksi virus HIV dan kerusakan jaringan limfoid semakin menyebar. Progresivitas penyakit ini akan berakhir pada tahap yang mematikan yang dikenal sebagai AIDS. Pada keadaan ini kerusakan sudah mengenai seluruh jaringan limfoid dan jumlah $\mathrm{CD}^{+}$sel $\mathrm{T}$ dalam darah turun di bawah 200 $\mathrm{sel} / \mathrm{mm}^{3}$ (normal $1.500 \mathrm{sel} / \mathrm{mm}^{3}$ ). Penderita AIDS dapat mengalami berbagai macam infeksi oportunistik, keganasan, cachexia (HIV wasting syndrome), gagal ginjal (HIV nefropati), dan degenerasi susunan saraf pusat (AIDS ensefalopati). Oleh karena $\mathrm{CD} 4^{+}$sel $\mathrm{T}$ sangat penting dalam respons imun selular dan humoral pada berbagai macam mikroba, maka kehilangan sel limfosit ini merupakan alasan utama mengapa penderita AIDS sangat rentan terhadap berbagai macam jenis infeksi. ${ }^{9}$

\section{GAMBARAN KLINIS}

Gambaran klinis infeksi HIV terdiri atas tiga fase sesuai dengan perjalanan infeksi HIV itu sendiri, yaitu: ${ }^{12}$ Serokonversi, Penyakit HIV asimtomatik, Infeksi HIV simtomatik atau AIDS

\section{Serokonversi}

Serokonversi adalah masa selama virus beredar menuju target sel (viremia) dan antibodi serum terhadap HIV mulai terbentuk. Sekitar $70 \%$ pasien infeksi HIV primer menderita sindrom mononucleosis-like akut yang terjadi dalam 2 hingga 6 minggu setelah infeksi awal, yang dikenal juga sebagai sindrom retroviral akut (acute retroviral syndrome; ARS). Sindrom ini terjadi akibat infeksi awal serta penyebaran HIV dan terdiri dari gejala-gejala yang tipikal, namun tidak khas. Sindrom ini memiliki bermacammacam manifestasi, gejala yang paling umum mencakup demam, lemah badan, mialgia, ruam kulit, limfadenopati, dan nyeri tenggorokan (sore throat). Selama masa ini terjadi viremia yang sangat hebat dengan penurunan jumlah limfosit CD4. ${ }^{13,14}$

\section{Penyakit HIV Asimtomatis}

Setelah infeksi HIV akut dengan penyebaran virus dan munculnya respons imun spesifik HIV, maka individu yang terinfeksi memasuki tahap kedua infeksi. Tahap ini dapat saja 


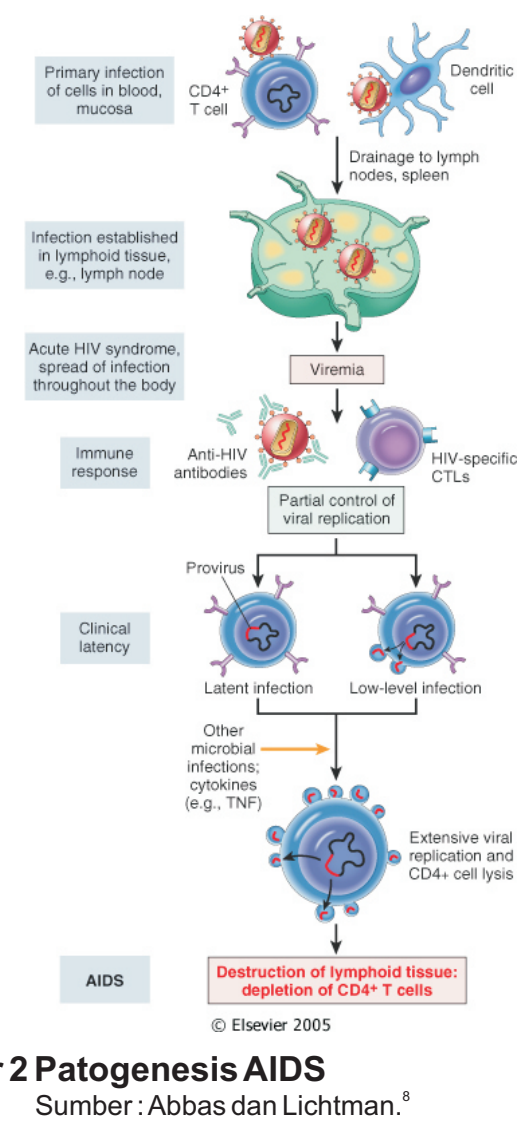

asimtomatis sepenuhnya. Istilah klinis 'laten' dulu digunakan untuk menandai tahap ini, namun istilah tersebut tidak sepenuhnya akurat karena pada tahap laten sejati (true latency), replikasi virus terhenti sementara. ${ }^{9,10}$

Jika tidak diobati masa laten infeksi HIV dapat berlangsung 18 bulan hingga 15 tahun bahkan lebih, rata-ratanya 8 tahun. Pada tahap ini penderita tidak rentan terhadap infeksi dan dapat sembuh bila terkena infeksi yang umum. Jumlah CD4 sel T secara perlahan mulai turun dan fungsinya semakin terganggu. Penderita dengan masa laten yang lama, biasanya menunjukkan prognosis yang lebih baik. ${ }^{9,10}$

\section{Infeksi HIV simtomatik atau AIDS.}

Jika terjadi penurunan jumlah sel CD4 yang meningkat disertai dengan peningkatan viremia maka hal tersebut menandakan akhir masa asimtomatik. Gejala awal yang akan ditemui sebelum masuk ke fase simtomatik adalah pembesaran kelenjar limfe secara menyeluruh (general limfadenopati) dengan konsistensi kenyal, mobile dengan diameter 1 $\mathrm{cm}$ atau lebih. Seiring dengan menurunnya jumlah sel $\mathrm{CD}^{+}$dan meningkatnya jumlah virus di dalam sirkulasi akan mempercepat terjadinya infeksi oportunistik. ${ }^{9}$

Sebagian besar permasalahan yang berkaitan dengan infeksi HIV terjadi sebagai akibat langsung hilangnya imunitas selular (cell- mediated immunity) yang disebabkan oleh hancurnya limfost T-helper $\mathrm{CD}^{+}$. Orang dengan penurunan jumlah sel $\mathrm{CD}^{+}$hingga kurang dari $200 \mathrm{sel} / \mathrm{mm}^{3}$ dikatakan menderita AIDS, meskipun kondisi ini tidak disertai dengan adanya penyakit yang menandai AIDS (Tabel 1). Definisi ini mencerminkan peningkatan kecenderungan timbulnya masalah yang berkaitan dengan HIV yang menyertai rendahnya jumlah sel $\mathrm{CD}^{+}{ }^{+}$secara progresif. Setelah AIDS terjadi, maka sistem imun sudah sedemikian terkompensasi sehingga pasien tidak mampu lagi mengontrol infeksi oleh patogen oportunis yang pada kondisi normal tidak berproliferasi, serta menjadi rentan terhadap terjadinya beberapa keganasan. Pasien dengan AIDS yang tidak diobati rata-rata meninggal dalam jangka waktu satu hingga tiga tahun.

Terapi yang telah tersedia saat ini telah memperbaiki prognosis pasien infeksi HIV secara signifikan. ${ }^{8}$

\section{TRANSMISI}

Transmisi HIV secara umum dapat terjadi melalui empat jalur, yaitu: ${ }^{11}$

Kontak seksual: HIV terdapat pada cairan mani dan sekret vagina yang akan ditularkan virus ke sel, baik pada pasangan homoseksual atau heteroseksual. Kerusakan pada mukosa genitalia akibat penyakit menular seksual seperti sifilis dan chancroid akan memudahkan terjadinya infeksi HIV.

Tranfusi: HIV ditularkan melalui tranfusi darah baik itu tranfusi whole blood, plasma, trombosit, atau fraksi sel darah lainnya.

Jarum yang terkontaminasi: transmisi dapat terjadi karena tusukan jarum yang terinfeksi atau bertukar pakai jarum di antara sesama pengguna obat-obatan psikotropika.

Transmisi vertikal (perinatal): wanita yang teinfeksi HIV sebanyak 15-40\% berkemung-kinan akan menularkan infeksi kepada bayi yang baru dilahirkannya melalui plasenta atau saat proses persalinan atau melalui air susu ibu.

\section{DIAGNOSIS LABORATORIUM}

Diagnosis laboratorium yang dapat dilakukan adalah:" isolasi virus HIV, serologi dengan menggunakan enzyme-linked immunosorbent assays (ELISA) atau tes aglutinasi, deteksi asam nukleat atau antigen: pengujian amplifikasi seperti reverse trancriptase-polymerase chain reaction (RT-PCR), dan imunologi: nilai absolut limfosit CD4 dan rasio CD4:CD8 rendah pada orang yang terinfeksi HIV. 
- Kandidiasis: esofageal, trakeal, atau bronkial

- Koksidiomikosis, ekstrapulmoner

- Kriptokokosis, ekstrapulmoner

- Kanker serviks, infasif

- Kriptosporidiosis, intestinal kronik (>1 bulan)

- $\quad$ CMV renitis, atau CMV di hati, limpa, nodul limfatik

- Enselopati HIV

- Herpes simpleks dengan ulkus mukokutaneus $>1$ bulan, bronkitis atau pneumonia

- Histoplasmosis: tersebar atau ekstrapulmoner

- Isosporiasis, kronik > 1 bulan

- Kaposi sarkoma

- Limfoma: Burkitt, imunoblastik, khususnya di otak

- $\quad$ M. avium atau M. kansasii, ekstrapulmoner

- M. tuberculosis, pulmoner atau ekstrapulmoner

- Pneumonia Pneumosistis carinii

- Pneumonia, bakteri rekurens (= 2 episode per tahun)

- Leukoensepalopati multifokal

- Bakteremia salmonela

- Toksoplasmosis, serebral

- Wasting syndrome HIV

Sumber: National Institute of Allergy and Infectious Diseases. ${ }^{9}$

\section{EFEK KEHAMILAN PADAAIDS}

Kadar plasma HIV dan sel CD4 merupakan penanda beratnya penyakit. Kadar rata-rata CD4 pada orang dewasa sehat $500-1.500 \mathrm{sel} / \mu \mathrm{L}$. Pada semua wanita hamil kadar CD4 menurun $543 \pm 169 \mathrm{sel} / \mu \mathrm{L}$ tetapi tidak menggambarkan terinfeksi atau tidaknya wanita tersebut oleh HIV. Kehamilan tidak dihubungkan dengan beratnya AIDS. ${ }^{3,13}$

\section{EFEKAIDS PADA KEHAMILAN}

Infeksi HIV meningkatkan insidensi gangguan pertumbuhan janin dan persalinan prematur pada wanita dengan penurunan kadar CD4 dan penyakit yang lanjut. Tidak ditemukan hubungan kelainan kongenital dengan infeksi $\mathrm{HIV}^{3,13}$

\section{Antenatal care wanita hamil dengan HIV}

Semua wanita hamil HIV positif harus dilakukan pemeriksaan yang ketat dan dilakukan juga pengobatan terhadap infeksi genital selama kehamilannya. Hal ini harus dilakukan sedini mungkin. ${ }^{13}$

Pengukuran kadar plasma dan CD4 limfosit $T$ harus diulang 4-6 kali setiap bulan selama kehamilannya dan dianjurkan terapi antivirus serta dibutuhkan terapi profilaksis untuk Pneumocystis carinii pneumonia (PCP). Profilaksis PCP biasanya diberikan bila kadar CD4 limfosit T di bawah 200 sel/ $\mu \mathrm{L}$ dalam bentuk kotrimoksazol (sulfametoksazol $800 \mathrm{mg}$ dan trimetoprin $160 \mathrm{mg}$ ) sekali sehari. ${ }^{3}$

Wanita yang sedang pengobatan HAART harus dilakukan monitoring terhadap intoksikasi obat seperti jumlah sel darah, ureum, elektrolit, fungsi hepar, laktat, dan gula darah. Adanya gejala dan tanda preeklamsi, kolelitiasis, atau gangguan fungsi hati selama kehamilan menandakan adanya intoksikasi obat. $^{3,13}$

Ultrasonografi (USG) mendetail tentang adanya anomali janin sangat penting dilakukan terutama wanita hamil yang telah terpapar obat HAART dan antagonis folat yang digunakan untuk profilaksis $\mathrm{PCP} .^{13}$

Monitoring janin intensif termasuk adanya gangguan anatomi, gangguan pertumbuhan, dan fetal well being pada saat trisemester III diharuskan pada ibu hamil yang mendapat obat kombinasi HAART untuk melihat efek obat pada janin. ${ }^{3,13}$

\section{TRANSMISI VERTIKAL}

Transmisi penyakit dari ibu ke janin (mother-tochild trasmission = MTCT) dapat terjadi selama kehamilan, saat persalinan, dan menyusui. Pada ibu hamil yang tidak diberikan obat HAART selama kehamilan, $80 \%$ terjadi transmisi MTCT pada usia kehamilan lanjut (di atas 36 minggu), saat persalinan, dan postpartum dan kurang dari $2 \%$ transmisi MTCT terjadi selama trisemester I dan II kehamilan. Tidak adanya intervensi dengan obat HAART, risiko transmisi MTCT pada ibu yang menyusui sebesar $15-20 \%$ dan $25-40 \%$ pada ibu yang menyusui bayinya. Adanya intervensi dengan obat HAART, seksio sesaria, dan tidak menyusui akan menurunkan risiko trasmisi MTCT dari $25-30 \%$ menjadi $<2 \%$. Pada ibu hamil dengan HIV yang lanjut, kadar CD4 limfosit $T$ antenatal yang rendah, dan tingginya kadar virus HIV dihubungkan dengan 


\section{PENGOBATAN}

Perkembangan dan percobaan klinis terhadap kemampuan obat antiretrovirus yang sering dikenal dengan highly active antiretroviral therapy (HAART) untuk menghambat HIV terus dilakukan selama 15 tahun terakhir ini. Pengobatan diharapkan mampu menghambat progresivitas infeksi HIV untuk menjadi AIDS dan penularannya terhadap orang lain serta janin pada wanita hamil. HAART menunjukkan adanya penurunan jumlah penderita HIV yang dirawat, penurunan angka kematian, penurunan infeksi oportunistik, dan meningkatkan kualitas hidup penderita. HAART bisa memperbaiki fungsi imunitas tetapi tidak dapat kembali normal. ${ }^{13,14}$

Pengobatan dengan menggunakan HAART yang aman saat ini pada wanita hamil adalah dengan menggunakan AZT (azidotimidin) atau ZDV (zidovudin). Pengobatan wanita hamil dengan menggunakan regimen AZT ini dibagi atas tiga bagian, yaitu: ${ }^{15,16}$ wanita hamil dengan HIV positif, pengobatan dengan menggunakan AZT harus dimulai pada usia kehamilan 14-34 minggu dengan dosis $100 \mathrm{mg}, 5$ kali sehari, atau $200 \mathrm{mg} 3$ kali sehari, atau $300 \mathrm{mg} 2$ kali sehari, pada saat persalinan; AZT diberikan secara intravena, dosis inisial $2 \mathrm{mg} / \mathrm{kgBB}$ dalam 1 jam dan dilanjutkan $1 \mathrm{mg} / \mathrm{kgBB} / \mathrm{jam}$ sampai partus, terhadap bayi diberikan AZT dengan dosis 2 $\mathrm{mg} / \mathrm{kgBB}$ secara oral atau $1,5 \mathrm{mg} / \mathrm{kgBB}$ secara intravena tiap 6 jam sampai usianya 4 minggu.

\section{Jenis Persalinan}

Wanita hamil dengan viral load $<50 \mathrm{kopi} / \mathrm{mL}$ saat pemberian HAART pada usia kehamilan 36 minggu dianjurkan melahirkan pervaginam. Keadaan ini tidak dianjurkan pada riwayat operasi dinding rahim, adanya kontraindikasi melahirkan pervaginam, infeksi genitalia berulang, dan diprediksi persalinannya akan berlangsung lama. ${ }^{3,13}$

Wanita hamil dengan HIV positif, tetapi tidak mendapat pengobatan HAART selama kehamilannya, seksio sesaria merupakan pilihan untuk mengurangi transmisi MTCT. . $^{3,13}$

\section{Penatalaksanaan Saat Persalinan \\ Persalinan pervaginam}

Wanita hamil yang direncanakan persalinan pervaginam, diusahakan selaput amnionnya utuh selama mungkin. Pemakaian eleklroda fetal scalp dan pengambilan sampel darah janin harus dihindari. Jika sebelumnya telah diberikan obat HAART, maka obat ini harus dilanjutkan sampai partus. Jika direncanakan pemberian infus zidovudin, harus diberikan pada saat persalinan dan dilanjutkan sampai tali pusat diklem. Dosis zidovudin adalah: dosis inisial 2 $\mathrm{mg} / \mathrm{kgBB}$ dalam 1 jam dan dilanjutkan 1 $\mathrm{mg} / \mathrm{kgBB} / \mathrm{jam}$ sampai partus. Tablet nevirapin dosis tunggal $200 \mathrm{mg}$ harus diberikan di awal persalinan. Tali pusat harus diklem secepat mungkin dan bayi harus dimandikan segera. Seksio sesaria emergensi biasanya dilakukan karena alasan obstetrik, menghindari partus lama, dan ketuban pecah lama. ${ }^{3}$

\section{Seksio Sesaria}

Pada saat direncanakan seksio sesaria secara elektif, harus diberikan antibiotik profilaksis. Infus zidovudin harus dimulai 4 jam sebelum seksio sesaria dan dilanjutkan sampai tali pusat diklem. Sampel darah ibu diambil saat itu dan diperiksa viral load-nya. Tali pusat harus diklem secepat mungkin pada saat seksio sesaria dan

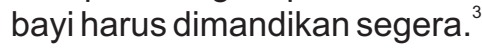

\section{Pemberian Makanan Bayi}

Apabila ibu memilih memberikan ASI, maka dianjurkan memberikan ASI secara eksklusif selama 6 bulan. ${ }^{14}$

Apabila tidak dapat memberikan ASI eksklusif, maka dianjurkan untuk segera beralih ke pemberian susu formula. ${ }^{14}$

Apabila syarat AFASS (acceptable, feasible, affordable, sustainable, safe) tercapai sebelum usia 6 bulan, maka ibu boleh beralih ke pemberian susu formula dan pemberian ASI dihentikan. ${ }^{14}$

\section{PENCEGAHAN}

HIV sering ditransmisikan melalui darah, sehingga usaha pencegahan dilakukan dengan beberapa cara, antara lain: ${ }^{17}$ meskipun asimtomatik setiap individu yang terinfeksi HIV dapat menularkan-nya kepada individu yang lain, sehingga dibutuhkan pemeriksaan kesehatan rutin.

Individu yang terinfeksi dilarang untuk menjadi pendonor baik itu donor darah, plasma, organ tubuh, jaringan, atau sperma.

Seluruh peralatan yang dapat berkontaminasi dengan darah seperti sikat gigi atau alat cukur tidak boleh digunakan bersama.

Tabel 2 Faktor-Faktor Risiko Transmisi Vertikal HIV

\begin{tabular}{ll}
\hline \multicolumn{1}{c}{ Faktor ibu } & \multicolumn{1}{c}{ Keja dian Intrapartum } \\
\hline Kadar CD4 yang rendah & Ketuban pecah dini buatan \\
Tingginya kadar viral load & Ketuban pecah dini $>4$ jam \\
Korioamnionitis & Penggunaan alat-alat pada persalinan \\
AIDS yang lanjut & Persalinan prematur \\
Adanya antigen 24 dalam serum ibu & Penggunaan scalp monitor \\
\hline Sumber: Tripathi dkk. &
\end{tabular}


Penderita HIV harus mengatakan kepada pihak medis bahwa mereka terinfeksi dan bila membutuhkan perawatan kesehatan harus mendapatkan perawatan khusus sesuai dengan prosedur penanganan penderita HIV untuk menghindari penularan kepada orang lain.

Pemeriksaan antibodi HIV harus diberikan terhadap orang yang bertendensi berkontak dengan penderita seropositif seperti pasangan seksual, orang yang sering bertukar pakai jarum, dan bayi yang dilahirkan dari ibu seropositif.

\section{DAFTAR PUSTAKA}

1. Watts DH. Human immnunodeficiency virus. Dalam: James DK, Steer PJ, Weiner CP, Gonik $B$, editor. High risk pregnancy management options. Edisi ke-3. USA: Saunders Elsevier; 2006. hlm. 620-35.

2. Sweet RL, Minkoff H. Maternal infection, human immunodeficiency virus infection, and sexually trasmitted diseases in pregnancy. Dalam: Reece EA, Hoobins JC, editor. Clinical obstetrics the fetus and mother. Edisi ke-3. Massachusetts: Blackwell Publishing; 2007. hIm. 885-930.

3. Goering RV, Dockrell HM, Zuckerman M, Walekin D, Roitt IM, Mims C, et al. Medical microbiology. Edisi ke-4. China: Mosby Elseiver; 2008. hlm. 261-86.

4. Tripathi R, Tyagi S, Chanchal. HIV in obstetrics and gynaecology. Dalam: Gandhi G, Metha S, Batra S, editor. Infection in obstetrics and gynaecology. India: Jaypee Brothers Medical Publishers; 2006. hlm. 34-55

5. Brooks GF, Butel JS, Ornston LN, Jawetz E, Melnick, JL, Adelberg EA, et al. Medical microbiology. Edisi ke-24. USA: Prentice-Hall International Inc; 2007.

6. A Service of the U.S. Department of Health and Human Services. HIV and pregnancy (diunduh Oktober 2007). Tersedia dari: http://aidsinfo .nih.gov

7. Murray RP, Rosenthal KS, Pfaler MA. Medical microbiology. Edisi ke-5. Pennsylvania: Mosby Elsevier; 2005.
8. Abbas AK, Lichtman AH. Cellular and molecular immunology. Edisi ke-5. Philadelphia: Saunders; 2003.

9. National Institute of Allergy and Infectious Disease. Treatment of HIV infection (diunduh November 2007). Tersedia dari: http://www.niaid.nih.gov/factsheet/treathiv.htm

10. Greenwood D, Slack R, Peutherer J, Barer M. Medical microbiology: a guide to microbial infections: pathogenesis, immunity, laboratory diagnosis and control. Edisi ke-17. UK: Churchill Livingstone; 2007.

11. McCutchan A. HIV infection and AIDS pathogenesis (diunduh 29 November 2007). Tersedia dari: www.hivtraining.ucsd.edu /powerpoint/HIV_AIDS_Pathogenesis_104.ppt

12. John Hopkins Blooberg School of Public Health. Population report; Family planing choices for women with HIV. 2007 Agustus; 5 (serial L).

13. Cunningham FG, Leveno KJ, Bloom SL. Hauthh JC, Gilstrap III LC, Wenstrom KD. Williams obstetrics. Edisi ke-22. USA: McGraw-Hill; 2005.

14. Syamsuri AK. Breastfeeding in HIV infection. Dibacakan dalam PIT X Fetomaternal, Malang, 2009.

15. Bernstein HB, Weinstein M. Normal pregnancy and prenatal care. Dalam: Decherney $\mathrm{AH}$, Nathan L, Goodwin TM, Laufer N, editor. Current diagnosis and treatment obstetrics and gynecology. Edisi ke-10. New York: McGrawHill; 2007. hlm. 187-202.

16. Toumala RE, Shapiro DE, Mofenson LM, Bryson $\mathrm{Y}$, Culname M, Hughes MD, et al. Antiretroviral therapy during pregnancy and the risk of an adverse outcome. N Eng J Med. 2002;346(24):1863-70.

17. De Bruyn M. Reproductive choice and women living with HIVIAIDS (diunduh 5 Oktober 2008). Tersedia dari: http://www.genderandaids.org /downloads/topics/Repro_Choice_HIV_AIDS. pdf 